\title{
Isolation and Characterization of Microbes with Biofertilizer Potential
}

\author{
Nimisha Vatsyayan ${ }^{1}$, Ashok K. Ghosh ${ }^{2}$ \\ ${ }^{1}$ (Department of EWM, A.N.College/MagadhUniversity ,India) \\ ${ }^{2}$ (Department of EWM, A.N.College/MagadhUniversity, India)
}

\begin{abstract}
Microorganisms work incognito to maintain the ecological balance by active participation in carbon, nitrogen, sulphur and phosphorous cycles in nature. Sampleswere collected from nearriver Ganga mainly Hazipur, Sonepur and Vaishali. Sites were dry field, banana field, wetland and stagnant pond areas. Isolation was done by serial dilution method in nutrient agar plate. The isolates were found to be maximum in humus rich soil of S1 (Banana field) soil (Hazipur) and S2 (Sedimented pond) soil. A total of 111 microbial strains (bacteria) were isolated. Strain which showed the best result was tested for its' biofertilizer potential on the paddy (Oryza sativa, variety - Sugandha) individually through pot experiment. The test isolate namely, S1(C) was selected on the basis of their luxuriant growth on NA. This isolate showed a wide range of temperature for growth between $4{ }^{\circ} \mathrm{C}$ to $55^{\circ} \mathrm{C}$ which suggests its potential as biofertilizer in field conditions where the organism has to survive under wide range of natural temperature fluctuations. The selected test isolate was Bacillus although molecular characterization (16s $r$-RNA studies) was done to confirm the genus and species of the selected isolate. On the basis of BLAST alignment of the sequenced nucleotides the isolate $S 1(C)$ was identified as Brevibacillusborstelensis. The reported literatures suggest that the B. borstelensisactsas $P G P R$.
\end{abstract}

Keywords:Bacteria, Biofertilizer potential, Oryza sativa, Biochemical test, Molecular characterization.

\section{INTRODUCTION}

The state of Bihar has been known for its agricultural and horticultural products. Its land is highly fertile mainly due to the revaluates of Ganges which carry a lot of growth promoting biotic and abiotic components for common crops. It is an estimated fact that microbes play direct or indirect roles in several biological activities that can be beneficial to mankind [1-5]. Microbiological techniques, especially in suppression of crop diseases, production of plant growth promoting substances and augmentation of nutrient recycling, offer a powerful tool in modern agriculture. Numerous species of soil bacteria which flourish in the rhizosphere of plants stimulate plant growth by a plethora of mechanisms. These bacteria are collectively known as PGPR (plant growth promoting rhizobacteria). The search for PGPR and investigation of their modes of action are increasing at a rapid pace as efforts are made to exploit them commercially as biofertilizers[6]. Many PGPR stimulate the growth of plants by helping to control pathogenic organism [7-8]. Thus, the present work focuses on the isolation and screening of soil microbes having biofertilizer potential from Gangetic planes of North Bihar. Microbes can be identified on the basis of their structural, biochemical and molecular characteristics based on their 16S rRNA sequences [9-12]. Thus, in our current studies, critical structural, biochemical and molecular identification of the isolated microbes were carried out and based on these findings; we have extended our work to access the biofertilizer potential of these microbes on rice, which is one of the major staple foods of the North Bihar. In recent years, biofertilizers have emerged as an important component of the integrated nutrient supply system and hold a great promise to improve crop yields through environmentally better nutrient supplies. The utilization of microbial products has several advantages over conventional chemicals for agricultural purposes. As far as the genetic characterization is concerned, only a limited number of microorganisms have been investigated in detail. The state of Bihar requires further more exploration for its microbial biodiversity, although it has highly fertile agricultural land in the North as well as South of river Ganges. The wetland and rain fed areas are little explored ecosystem which need immediate attention to isolate and screen microbes that help in enhanced soil fertility and decomposition of agricultural wastes. The Gangetic plane of north Bihar is one such niche where the possibilities of finding microorganisms for biofertilizer potentials are more apparent. The state of Bihar, after bifurcation, is largely dependent on the agricultural produces. Although a lot of efforts have been made by researchers to develop crop varieties that best suit the soil of Bihar, very little effort has been made to investigate the soil microflora that supports and promotes the growth of crops even without addition of fertilizers, especially of the most fertile Indo-Gangetic planes. Biofertilizer has been identified as an alternative to chemical fertilizer to increase soil fertility and crop production in sustainable farming. 
Biofertilizers are products containing living cells of different types of microorganisms, which have an ability to convert nutritionally important elements from unavailable to available form through biological processes [6]. In recent years, biofertilizers have emerged as an important component of the integrated nutrient supply system and hold a great promise to improve crop yields through environmentally better nutrient supplies. The utilization of microbial products has several advantages over conventional chemicals for agricultural purposes.

\section{Sources of sample collection}

\section{MATERIALS AND MeTHODS}

In this investigation, soil samples were collected from five different sampling sites which were spread near river Ganga mainly Hazipur, Sonepur and Vaishali. The sample sites were dry field, banana field, wetland and stagnant pond areas. The sampling was also dependent on variation of time, duration and season. The sampling seasons were monsoon (July), post monsoon (October), winter season (January), and spring season (April). All sampling stations of the selected sampling sites were periodically visited and soil samples were collected with all precautions and sincerity.

\section{Methods of sample collection}

Due care was taken during sample collection. Samples were collected from varying depth from 3 to 6 inches. These soil samples were collected in separate sterilized sampling bottles. Each sample bottle was labeled properly with soil type, location, date etc., once they were filled with sample. After sample collection all samples were placed in cool and moist place for the purpose of microbial survival.

\section{Isolation, purification and maintenance of bacterial strains}

The strains of bacteria were selectively isolated from the mixed population of microbes growing on the nutrient agar (NA) medium by single colony isolation. The composition of NA was ( $\left.\mathrm{g} \mathrm{l}^{-1}\right)$ : peptone, 5; beef extract, 3; NaCl, 5; agar- agar, 16. The pure culture of isolate consisting of only a single type of species was picked up with the help of sterile needle. The purity of isolates was maintained by subsequent microscopic and physiological studies, as the microbial studies involve the use of pure culture. Streak plate method was also used for obtaining pure culture, as and when required. For single colony isolation, all these strains were properly diluted $(1: 10: 100,1: 1000,1: 10000)$ before plating on the suitable media. These plates were kept at a temperature ranging from $27^{\circ} \mathrm{C}$ to $37^{\circ} \mathrm{C}$, separately. The organisms were allowed to incubate on NA medium for a maximum period of 7 to 12 days. However, the plates were examined every day with respect to their growth, morphology and number of colonies per plate. Colour of the colonies and pigment secretion of the isolates, if any, on the media and even the colony size were also examined.

\section{Pot experiments on Oryza sativa sugandha (rice) for the determination of biofertilizer potential of bacterial isolates}

The soil for the pot experiments was collected from A.N. College, Patna garden and sterilized by autoclaving to remove any microbes already available in soil. The sterilized soil was used as control wherever applicable. The commercial biofertilizer was obtained from TaruMitraBiofertilizers (procured from TaruMitra center, East Boring Canal road). The bacterial isolate from Gangetic soil namely S1 (C) was used as nutrient broth. Three types of soil combinations containing control soil, control soil with market procured biofertilizer (TaruMitra biofertilizer) and control soil with bacterial isolate S1(C) was prepared and filled in separate labeled pots. The pots were immediately sowed with the rice seeds under exposed sunlight condition. All the plants were grown in similar natural environmental conditions. The comparative evaluation of vegetative as well as reproductive growth patterns of plants grown in different soil combinations were made periodically for more than 120 days. Crop development data were collected on an average interval of 10-23 days from the sowing of seeds to maturation of new seeds. The various observed parameters to determine both vegetative as well as reproductive plant growth patterns were date of sowing, date of germination, number of plants germinated, number of leaves, length of leaves, colour of leaves, length of plants, growth of inflorescence, number of fruits, quality of fruits, number of seeds. The data were recorded, tabulated and compared to determine the biofertilizer potential of isolates. 


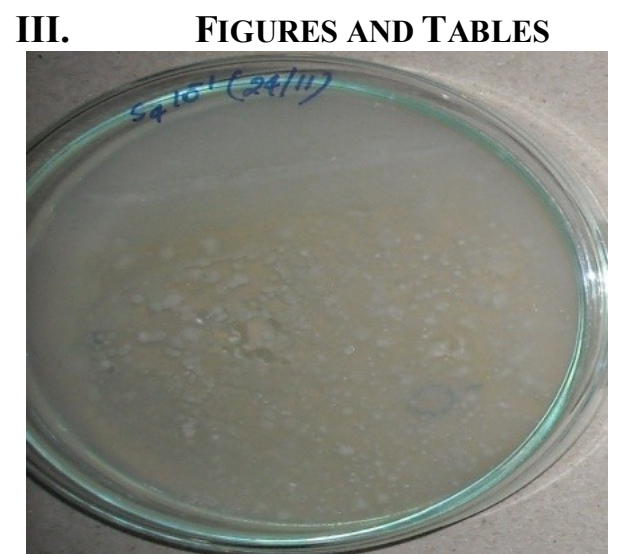

Fig. 1.1 NA plate showing purified bacterial colonies.

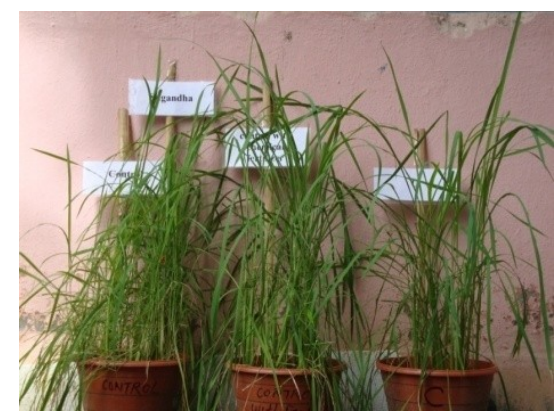

Fig.1.2First observation of plants growing in control, control with TaruMitrabiofertilizer and control with bacterial isolate $\mathrm{S} 1(\mathrm{C})$.

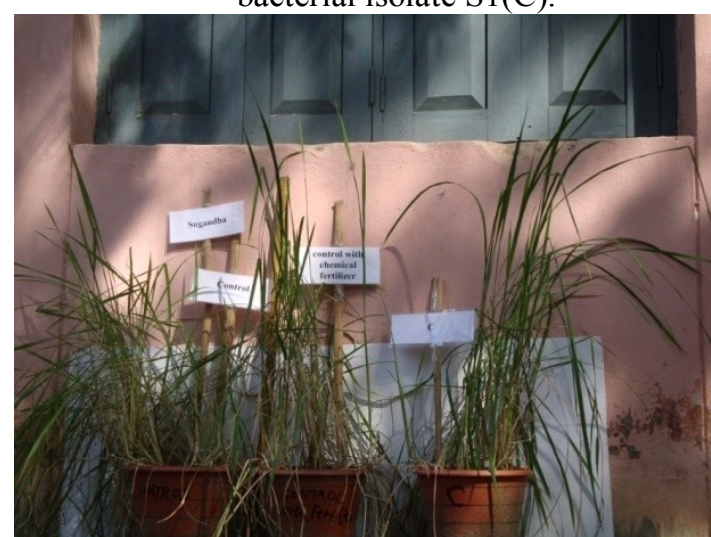

Fig.1.3Last observation of plants growing in control, control with TaruMitra biofertilizer and control with bacterial isolate $\mathrm{S} 1(\mathrm{C})$.

\begin{tabular}{|c|c|c|}
\hline \multirow[t]{2}{*}{ Methods } & \multirow[t]{2}{*}{ Properties } & Bacterial isolate \\
\hline & & $\mathrm{S} 1(\mathrm{C})$ \\
\hline \multirow[t]{4}{*}{ Gram's staining } & Gram's reaction & $+\mathrm{ve}$ \\
\hline & Cell shape & Rods \\
\hline & Size $(\mu \mathrm{m})$ & $4 \mu \mathrm{m}$ in length \\
\hline & Arrangement & $\begin{array}{l}\text { occurring singly as well as } \\
\text { in chains }\end{array}$ \\
\hline \multirow[t]{4}{*}{ Endospore staining } & Spores & $+\mathrm{ve}$ \\
\hline & Shape & Oval \\
\hline & Position & Central \\
\hline & Sporangia & $-\mathrm{ve}$ \\
\hline Light microscopy & Motility & $+\mathrm{ve}$ \\
\hline
\end{tabular}

-ve: negative, +ve: positive

Table 1.1.1 Morphological characterization of bacterial isolates. 


\begin{tabular}{|c|c|c|}
\hline \multicolumn{2}{|c|}{ Parameters } & \multirow{2}{*}{$\begin{array}{r}\text { Bacterial isolate } \\
\mathrm{S} 1(\mathrm{C}) \\
+\end{array}$} \\
\hline \multirow{8}{*}{ Temperature $\left({ }^{\circ} \mathrm{C}\right)$} & 4 & \\
\hline & 12 & + \\
\hline & 15 & + \\
\hline & 25 & + \\
\hline & 30 & + \\
\hline & 37 & + \\
\hline & 42 & + \\
\hline & 50 & + \\
\hline \multirow[t]{7}{*}{$\mathrm{NaCl}$ concentration $(\%)$} & 1 & + \\
\hline & 2 & + \\
\hline & 4 & - \\
\hline & 6 & - \\
\hline & 8 & - \\
\hline & 10 & - \\
\hline & 12 & - \\
\hline \multirow[t]{7}{*}{$\mathrm{Ph}$} & 5 & - \\
\hline & 6 & + \\
\hline & 7 & + \\
\hline & 8 & + \\
\hline & 9 & + \\
\hline & 10 & + \\
\hline & 11 & + \\
\hline
\end{tabular}

-: Absent, +: Present

Table 1.1.2 Physiological characterization of bacterial isolates.

\begin{tabular}{|c|c|}
\hline \multirow[t]{2}{*}{ Parameters } & Bacterial isolate \\
\hline & $\mathrm{S} 1(\mathrm{C})$ \\
\hline Indole test & -ve \\
\hline Methyl red test & -ve \\
\hline VogesProskauer test & -ve \\
\hline Citrate Utilisation & -ve \\
\hline $\mathrm{H}_{2} \mathrm{~S}$ production & $+\mathrm{ve}$ \\
\hline Gas production from Glucose & $+\mathrm{ve}$ \\
\hline Casein hydrolysis & -ve \\
\hline Gelatin hydrolysis & -ve \\
\hline Starch hydrolysis & -ve \\
\hline Urea hydrolysis & $+\mathrm{ve}$ \\
\hline Phosphatase & -ve \\
\hline Nitrate reduction & $+\mathrm{ve}$ \\
\hline Catalase test & $+\mathrm{ve}$ \\
\hline Oxidase test & -ve \\
\hline Arginine dihydrolase & -ve \\
\hline Ornithine decarboxylase & $+\mathrm{ve}$ \\
\hline Acid from Trehalose & -ve \\
\hline Acid from Arabinose & -ve \\
\hline Acid from Galactose & -ve \\
\hline Acid from Glucose & $+\mathrm{ve}$ \\
\hline Acid from Mannitol & -ve \\
\hline Acid from Raffinose & -ve \\
\hline Acid from Salicin & -ve \\
\hline Acid from Xylose & -ve \\
\hline Acid from Sucrose & ND \\
\hline Acid from Fructose & $+\mathrm{ve}$ \\
\hline
\end{tabular}

-ve: negative, +ve: positive, ND: Not determined

Table 1.1.3 Biochemical characterization of bacterial isolates.

\section{CONCLUSION}

Out of 111 isolates, 1 isolate was selected for their morphological, physiological and biochemical characterizations on the basis of their best growth in NA.

1. The bacterial isolate from soil varied widely in their colony morphology, spore and pigment production.

2. The isolate was Gram +ve.

3. The isolate could grow in wide range of temperature but $37^{\circ} \mathrm{C}$ was the optimum temperature for growth.However, the isolate S1 (C) shows a wide range of temperature for growth which is quite interesting property and suggests its potential as biofertilizer in field conditions where the organism has to survive under wide range of natural temperature fluctuations. 
4. The isolate grew in presence of low concentration of $\mathrm{NaCl}$ in the medium.

5. Neutral and alkaline conditions were favorable for the growth of isolate.

6. Only isolate $\mathrm{S} 1(\mathrm{C})$ could be used as nitrate reducer and did not acted as phosphate solubilizers.

7.The isolate $\mathrm{S} 1(\mathrm{C})$ did not show luxuriant growth on starch.

8. Out of the selected test isolates only this strain S1(C) could decarboxylate amino acid like ornithine but couldn't decarboxylate arginine.

9. Isolate was capable of producing acid from carbohydrate sources like glucose, sucrose, trehalose, maltose, arabinose, xylose, lactose, fructose and mannitol.

On the basis of above findings the test isolate was concluded as the species of genus Bacillus showing promising results for their applications as biofertilizers/PGPR.

On the basis of total growth pattern observation, results reveals that in the final stage the growth of plants growing in control with strain S1(C) combination was fastest, followed by plants growing in control with biofertilizer combination.

2. On the basis of total growth pattern observation, results reveals that the fruit body of the plants growing in control with strain S1(C) combination was most healthy with maximum number of seeds. This was followed by the fruit body of plants growing in control with bio fertilizer combination.

- Thus, the comparative vegetative and reproductive plant growth patterns of Oryza sativa (Rice) both individually as well as in combination of bacteria with soil were interesting and very encouraging.Investigation of biofertilizer activity in sterilized soil inoculated with selected isolate revealed superiority of the selected isolate as biofertilizer over market available biofertilizer (TaruMitra biofertilizer). Based upon biofertilizer potentiality as growth-promoting activity, selected isolate was designated as the best plant growth promoting bacteria.

- BLAST alignment of the sequenced nucleotides of the isolate S1(C) identified as strain of Brevibacillusborstelensis.

- As per the literature $B$. borstelensisis a plant growth promoting bacteria. Thus, the bacterial strain isolated from Gangetic soil can act as PGPRs. It has the potential to be used as biofertlizer which has already been established by our previous results.

\section{Acknowledgements}

Financial grant for the research from Department of Science and Technology (DST), Govt. of India is acknowledged.

\section{REFERENCES}

[1] BHA Rehm, Microbial production of biopolymers and polymer precursors,Applications andperspectives,Caister Academic Press2008.

[2] E Diaz, Microbial biodegradation, Genomics and molecular biologylst ed, Caister Academic Press2008.

[3] GW Tannock editor, Probiotics and Prebiotics, Scientific Aspects, Caister Academic Press 2005.

[4] Mengesha et al, Clostridia in Anti-tumor Therapy,Clostridia,Molecular Biology in the Post-genomic Era,Caister Academic Press 2009

[5] YBashan, Inoculants of plant growth-promoting bacteria for use in agriculture,Biotechnol Advances 16,1998,729-770.

[6] JK Vessey, Plant growth promoting rhizobacteria as biofertilizers, Plant and Soil 255,2003 571-586.

[7] JM Whipps, Microbial interactions and biocontrol in the rhizosphere, $J$ Exp Bot 52,2001,487-511.

[8] GW Zehnder, J.F.Murphy,E.J.Sikora, and J.W. Kloepper, Application to rhizobacteria for induced resistance,Eur J Plant Pathol107, 2001,39-50.

[9] H Stolp, Microbial ecology: Organisms, Habitats, Activities, Cambridge University Press, Cambridge, 1988

[10] J Seckbach, Journey to Diverse Microbial Worlds, Kluwer Academic Publishers, Dordrecht, vol2, 2000.

[11] R Budhiraja, A. Basu, and R. K. Jain, Microbial Diversity: Significance, conservation and application. SciLett25, 2002, 189-201.

[12] T Satyanarayana, C.Raghukumar, andS.Shivaji,Extremophilic microbes: diversity and perspectives, CurrSci89, 2005,78-90. 